\title{
EMBODIED ENERGY \\ OF STABILIZED RAMMED EARTH
}

\section{ENERGIA ZAWARTA \\ W STABILIZOWANEJ ZIEMI UBITEJ}

Abstract

The embodied energy of stabilized rammed earth refers to a number of sources to create a compact account of the intrinsic energy, physical parameters and subsequent thermal potential of rammed earth stabilized with Portland cement. The objective of this paper is to show that lower embodied energy does not reduce thermal comfort if careful consideration is given to design.

Keywords: CSRE (Cement Stabilized Rammed Earth), sandwich construction, solar passive architecture

Streszczenie

Energia zawarta w stabilizowanej ziemi ubitej odnosi się do szeregu źródeł umożliwiających dokładne obliczenie energii wewnętrznej, parametrów fizycznych oraz potencjału cieplnego ubijanej ziemi poddanej stabilizacji cementem portlandzkim. Celem niniejszego artykułu jest ukazanie, że niższy poziom energii nie zmniejsza komfortu cieplnego pod warunkiem, że projekt opracowany jest z dużą starannością.

Stowa kluczowe: ubita ziemia stabilizowana cementem, konstrukcja przektadana, architektura z pasywnym zastosowaniem energii stonecznej

\footnotetext{
* Eng. Clayton Stone, PhD. Eng. Miloslav Bagoňa, Prof. CSc. Dušan Katunský, Technical University in Košice.
} 


\section{Outline}

According to current information, a $300(\mathrm{~mm})$ thick rammed earth wall has an $\mathrm{R}$ value of between $0.35-0.70\left(\mathrm{~m}^{2} \mathrm{~K} / \mathrm{W}\right)$ [1]. Similarly the $U$-value for a $300(\mathrm{~mm})$ thick rammed earth wall can be as much as $1,9\left(\mathrm{~W} / \mathrm{m}^{2} \mathrm{~K}\right)$ [2]. Houben and Guillard [3], that rammed earth has a thermal storage of $1830\left(\mathrm{~kJ} / \mathrm{m}^{3} \mathrm{~K}\right)$ [3].The $R$ and $U$ values of cement stabilized rammed earth is as much discussed as is its thermal mass. There will always be moisture present, absorbed onto clay particles or, at the most extreme temperatures, held within the cement matrix (although that is not free water). The balancing of these two properties is subject to much conjecture. As a result, rammed earth by itself has poor insulating properties. By using a sandwich construction you can effectively increase the thermal performance of the construction without proportionately increasing the dimensions of the envelope.

\section{INSULATED RAMMED EARTH}

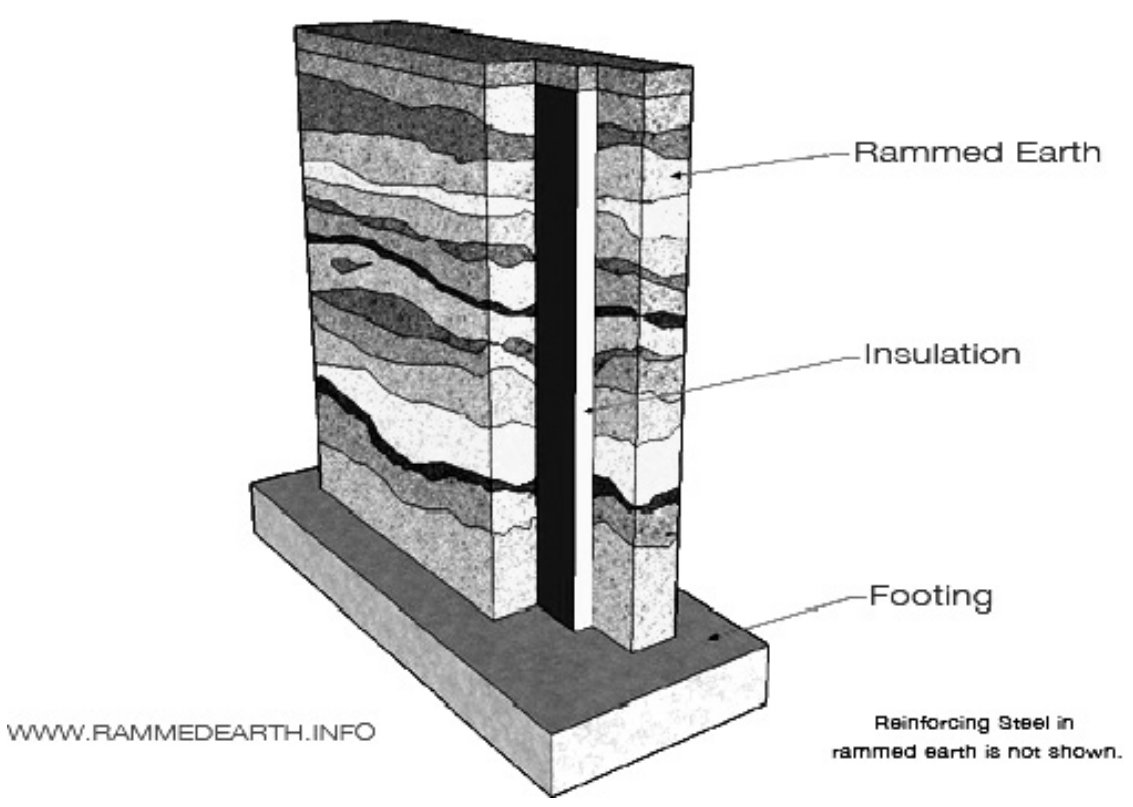

Fig 1. Insulated rammed earth [5]

Rys. 1. Izolowana ziemia ubita [5]

For a cavity cement stabilized rammed earth (CSRE) wall with $175(\mathrm{~mm})$ inner \& outer leaves incorporating polyisocyanurate solid cavity insulation and stainless steel wall ties;

$$
\begin{aligned}
& U \text {-value }=0.335\left(\mathrm{~W} / \mathrm{m}^{2} \mathrm{~K}\right) \text { for } 50(\mathrm{~mm}) \text { thick insulation } \\
& U \text {-value }=0.245\left(\mathrm{~W} / \mathrm{m}^{2} \mathrm{~K}\right) \text { for } 75(\mathrm{~mm}) \text { thick insulation }
\end{aligned}
$$

Approximate thermal time lag $=6-8(\mathrm{~h})$ 


\section{CSRE passive energy potential}

Rammed earth is generally suited to passive solar design as its high mass contributes to the regulation of internal temperature and humidity, reducing the need for active heating and air conditioning systems. Basic principles of good architectural design for CSRE as a response to Central European climates, where demand for winter heating exceeds that for summer cooling and the winter days are typically clear and sunny, include large south-facing windows and thermal mass floors to reduce heating loads. North facing walls should be especially well insulated and if possible protected using natural features such as trees. Natural sunlight plays an important role in contributing to the comfort of a house. Buildings should be designed so that they trap heat during the winter while producing shade in the summer. The building should ideally be rectangular in plan with an overall length of 1.5 to 2 times the width [2]. The building's longitudinal axis should be aligned east west and the south face (northern hemisphere) should have the most glazing (15-20\% of the floor area) to allow the warmth of the winter sun to enter the building. A suitable eaves length promotes the infiltration of sunlight in the winter whilst shading against higher summer sun. Lower angle sun can penetrate living spaces through careful positioning of skylights, whilst summer shading can be provided by deciduous plants or created artificially using louvers screens and blinds. A good solar orientated structure can decrease energy consumption considerably. Heat is accumulated within the building elements and effectively distributed within the building. This natural heat environment is far healthier than any known artificial system.

\section{Architecture and environment energy implications}

Unlike vernacular architecture which provided more or less climatically comfortable living spaces with a minimum use of external energy, conventional modern architecture with all its achievements is however heavily dependent on commercial energy sources for providing lighting, heating and cooling in buildings. This puts tremendous strain on conventional energy - which is easy to access - thus aiding the release of energy into the atmosphere and related manifestations like green house effects, and further damage to the environment. According to estimates, during the last 100 years or so, global civilization has released almost the same amount of energy into the atmosphere as has been done by our ancestors in the last 5000 years.

\section{Conservation of energy}

The aim of reducing the strain on conventional energy is achieved through conservation of energy by means of:

1. Low energy buildings - efficient structural design, reducing the qualities of high-energy building material and transportation energy.

2. Solar passive architecture - climate responsive architecture that conserves energy otherwise used for heating, cooling and interior lighting by taking into account solar radiation and other ambient conditions in the area and by incorporating features such appropriate building materials, appropriate shape, orientation, insulation, shading devices etc.

3. Creating low energy demands of energy - through efficiency. 
Ecological comparison of building materials [6]

\begin{tabular}{|c|c|c|c|c|}
\hline Product & $\begin{array}{c}\text { Thickness } \\
{[\mathrm{cm}]}\end{array}$ & $\begin{array}{c}\text { Units } \\
\text { Per }\left[\mathrm{m}^{2}\right]\end{array}$ & $\begin{array}{c}\text { Energy required for } \\
\text { production } \\
{\left[\mathrm{MJ} \text { per }^{3}\right]}\end{array}$ & $\begin{array}{c}\mathrm{CO}_{2} \text { emissions } \\
{\left[\mathrm{kg} \mathrm{per} \mathrm{m}^{2}\right]}\end{array}$ \\
\hline CSEB $(6 \%$ cement $)$ & 24 & - & 646 & 16 \\
\hline Fired brick & 23 & 112 & 2550 & 26 \\
\hline Hollow concrete block & 20 & 20 & 971 & 26 \\
\hline
\end{tabular}

As can be seen from the graph above, CSEB are require significantly less energy than its fired brick counterpart. This varies according to location and is also dependent on the cost of cement and any cost break down should take into consideration the influence that the local context has on the price.

Table 2

Energy Requirements [6]

\begin{tabular}{|c|c|c|c|c|}
\hline \multirow{2}{*}{ Material } & & \multirow{2}{*}{$\begin{array}{c}\text { Energy required for } \\
\text { production }[\mathrm{MJ}]\end{array}$} & \multicolumn{2}{|c|}{$\begin{array}{c}\text { Energy required for } \\
\text { transportation }[\mathrm{MJ}]\end{array}$} \\
\cline { 4 - 5 } & Unit & & $50[\mathrm{~km}]$ & $100[\mathrm{~km}]$ \\
\hline Sand & {$\left[\mathrm{m}^{3}\right]$} & 0.0 & 87.5 & 175 \\
\hline Crushed aggregate & {$\left[\mathrm{m}^{3}\right]$} & 20.5 & 87.5 & 175 \\
\hline Fire bricks & {$\left[\mathrm{m}^{3}\right]$} & 2550 & 100 & 200 \\
\hline Cement & {$[$ tonne] } & 5850 & 50 & 100 \\
\hline Steel & {$[$ tonne] } & 42000 & 50 & 100 \\
\hline
\end{tabular}

Surprisingly there are also energy savings to be had involving transport. In some instances, it is possible to use the soil that is available on sight for CSRE construction. Alternatively it is possible to add the missing material aggregates to available on sight soil to obtain the desired soil mixture. If neither of these cases is feasible and hypothetically speaking; the soil has to be transported the exact same distance that the fired bricks would need to be, it is still possible to save energy and minimize the ecological impact because soil requires less effort and time to load and unload, thereby saving fuel and consequently energy. 


\section{Renewable, Ecological, Sustainable}

Earth Building is a renewable technology because the material is simply borrowed from the earth for the life of the building and can be reused and recycled indefinitely as a building material or returned to the earth. The thermal mass of earth is commonly used to accumulate cold and warmth, balancing diurnal fluctuations in temperature in all seasons. Earth building is an appropriate, renewable, sustainable technology, exactly what the world needs today to provide safe, durable, comfortable and desirable homes. Modern examples worldwide demonstrate how far the technology has developed and why it's a common choice building material. It can be used to create buildings of any shape or style. It is raw and natural and has a low embodied energy and which can be manipulated into achieving optimal thermal mass and insulation by adjusting its density and thickness. The material is non-toxic, non-allergenic, controls humidity, is fire, rot and termite resistant, exhibits excellent sound insulation properties and therefore cement stabilized rammed earth can be used to create safe and healthy buildings, which is not surprising why it earned an "Excellent" rating from the internationally acclaimed BREEAM ratings. The material is abundant and widespread, uses very little energy in the entire process from raw earth to building, is durable, and its properties make it an excellent choice for climate responsive buildings.

\section{CSRE as a form of Passive Architecture}

In a passive approach, a building is designed to allow the sun to warm or not warm the interiors without any intermediary machinery. Insulated rammed earth envelope constructions are known as composite envelopes because the structural SRE leaf acts as a high thermal mass system $\left(1700-2100\left(\mathrm{~kg} / \mathrm{m}^{3}\right)\right)$ which helps produce a specific heat (c) that helps buffer day and night fluctuations. The insulation factor slows the passage of heat, but does not adequately reflect on thermal storage which strongly influences thermal physiological comfort. Occupants standing near a wall of high thermal mass receive a direct sensation of coolness or warmth regardless of the air temperature surrounding them. One of the effects of mass systems is that they alter the indoor air temperature considerably while changing their own temperature more gradually.

\section{Future collaboration}

The Civil Engineering Faculty at the Technical University of Kosice, through the Building and Environmental Institute, plans to research, develop, promote and transfer earth-based technologies and is currently cooperating with the assistance of Ramtec, Australia and the University of Western Australia and aims to conduct a comprehensive study of the thermal properties of cement stabilized earth with the goal of having it published in ASHRAE and in the building standards of Australia. The research will be conducted with the support of the 'Excellence research centre for integrated research of progressive building structures, materials and technologies" and all laboratory work will be undertaken at the Civil Engineering Faculty of the Technical University of Kosice. Research will focus on how various samples with differing material composition will react to thermal conditions designed for colder regions (Central Europe) and will include simulations. 


\section{Conclusions}

Building with earth seems to be an appropriate cost and energy effective technology. Obviously one has to know the material and master its disadvantages, so that rammed earth can once again be a modern building material and viable ecological alternative to mainstream load bearing envelope structure for central European conditions.

Supported by VEGA 1/1060/11: Monitoring of changes in physical parameters of the building envelope structures during quasi stationary states in regards to the dynamic changes of the external environment.

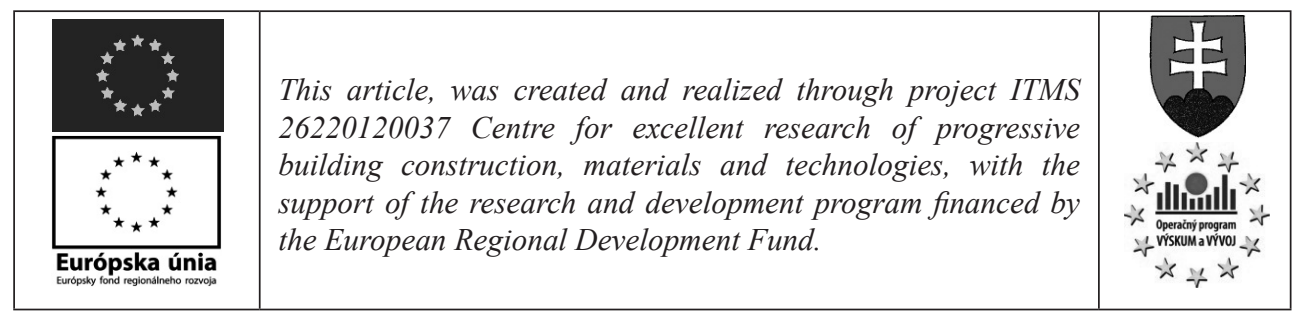

\section{Denotations}

$U$-value - the overall heat transfer coefficient, describes how well a building element conducts heat. It measures the rate of heat transfer through a building element over a given area, under standardized conditions.

$R$-value - a measure of the thermal resistance of a material used in the building industry.

\section{References}

[1] Standards Australia, The Australian Earth Building Handbook, Sydney 2002.

[2] Minke, Gernot, Building with Earth: Design and Technology of a Sustainable Architecture, Berlin, In: Birkhäuser Architecture; 2nd, rev. ed. Edition, January 16, 2009.

[3] Houben H., Guillaud H., Earth Construction, A comprehensive Guide, Intermediate Technology Publications, London 1994 (pdf).

[4] Craterre, Raw Earth Architecture, Renaissance of Architecture in France, CRATerre, Villefontaine, France 1990.

[5] Unesco Un-habitat (www.unhabitat.org/downloads/docs/3629_74602_Compressed.pdf).

[6] Development alternatives 1998 and Prof. B. V. Venkatarama Reddy Department of Civil Engineering, Indian Institute of Science Bangalore - 560012.

[7] Katunský D. et al., Centre for excellent research of progressive building constructions and indoor technology at the Building and Environmental Institute, Doctoral Seminar 2011 Building and Environmental Institute: 3. Year, Košice, TU, 2011, 8-12.

[8] Williamson T.J., Assessing the effectiveness for thermal mass in the building envelope, In: Proceedings of Building Simulation 2011: 12th Conference of International Building Performance Simulation Association, Sydney, 14-16 November 2011. 